\title{
Measurement of pulmonary artery pressure in cyanotic heart disease using selective coronary artery cannulation techniques
}

\author{
JAMES C DILLON \\ From the Krannert Institute of Cardiology, the Department of Medicine, Indiana University School of Medicine, and the \\ Veterans Administration Medical Center, Indianapolis, Indiana, USA
}

SUMMARY Measurement of pulmonary artery pressure remains a difficult procedure in certain forms of congenital heart disease. This paper reports the use of selective techniques developed for coronary artery cannulation and their application to a patient with cyanotic heart disease.

The measurement of pulmonary artery pressure and resistance is crucial in the management of older patients with cyanotic congenital heart disease. This is especially important in patients who have had previous palliative surgery or known right ventricular outlet obstruction. ${ }^{1}$ The ability to measure pulmonary artery pressure is often hampered by the presence of significant derangements of cardiac anatomy. ${ }^{2}$ Recently, in a patient who presented with complex cyanotic heart disease and a previous Blalock procedure, techniques developed for coronary balloon angioplasty ${ }^{34}$ and streptokinase infusion ${ }^{46}$ of the coronary arteries were used to measure pulmonary pressure through the Blalock anastomosis.

\section{Case report}

The patient was a 17 year old white girl who had been followed at Indiana University Medical Center since early in life. She had cyanotic congenital heart disease with transposition of the great arteries, a ventricular septal defect, and pulmonary stenosis, and had had Blalock procedures on the left side in 1969, and on the right side in 1976. She was known to have a right-sided aortic arch. After the second Blalock operation in 1976, there was no real improvement in oxygenation. The patient was lost to follow-up at that time until she returned in 1981 with a tubal pregnancy, requiring abdominal surgery and salpingo-oophorectomy after which she was referred back for further cardiac evaluation.

Supported in part by the Herman C Krannert Fund, and by grants trom the National Heart, Lung and Blood Institute of the National Institutes of Health, US Public Health Service, and the American Heart Association, Indiana Affiliate, Inc.
Physical examination showed a very cyanotic white girl of short stature. The chest was clear. Cardiac examination disclosed a lift at the left sternal border. The maximal cardiac impulse was displaced towards the anterior axillary line. The second heart sound was single. There was a pansystolic murmur along the left sternal border that radiated widely. No diastolic murmur was noted. There was also a systolic ejection murmur in the second left intercostal space. In the back, flow in a Blalock shunt could be heard loudest on the left. The rest of the examination was not remarkable except for clubbing of the extremities.

Laboratory data showed a haemoglobin of $18.2 \mathrm{~g}$ / $100 \mathrm{ml}$; a haematocrit of 58 ; white blood cell count of 7300 . Uric acid was $63 \mathrm{mg} / 100 \mathrm{ml}$. Other blood chemistry was normal. $\mathrm{PO}_{2}$ on arterial blood was $20 \mathrm{kPa}$ on room air.

Echocardiography showed both an atrial and a ventricular septal defect, but there was no evidence of an endocardial cushion defect. Both atrioventricular valves were shown to be present. The left ventricle appeared to be small, but not smaller than it should be for the patient's size. The right ventricle was slightly dilated. Transposition of the great arteries, d-type, was noted.

Right heart and retrograde left heart catheterisation was carried out without difficulty. Numerous attempts were made to enter the pulmonary artery from both the patient's arm and leg. The pulmonary artery could be visualised angiographically, but it was impossible to advance a catheter into it. Pressure analysis showed equalisation of pressure in the two ventricles. There was right to left shunting shown by an indicator dilution dye curve.

Angiograms were performed which showed dtransposition, a right sided arch, atrial septal defect, 


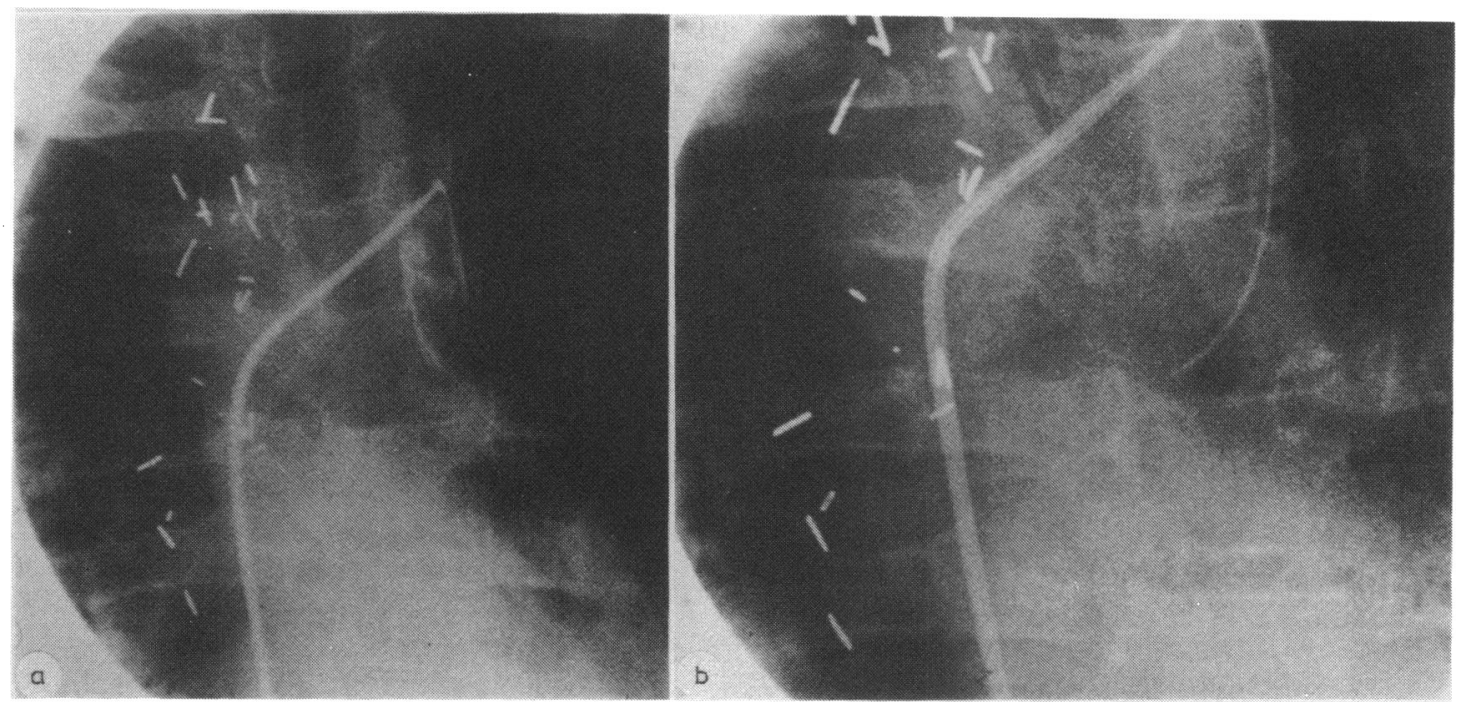

Fig. (a) A stopped framed angiogram showing the head hunter catheter in the orifice of the left subclavian artery. Contrast is seen to be streaming down, and a narrowing in the subclavian is shown above its insertion into the pulmonary artery. A right-sided aortic arch is also noted. (b) The small Teflon catheter is advanced through the lumen of the head hunter catheter and down the left subclavian artery into the main pulmonary artery. A double lumen effect can be noted in the body of the head hunter catheter.

and a ventricular septal defect. Angiographically, there appeared to be both pulmonary valvular stenosis, as well as subpulmonary stenosis. The pulmonary arteries were seen to fill with contrast material. The left Blalock anastomosis was visualised and selectively injected (Fig. a). It appeared to be stenotic before its insertion into the pulmonary artery. The right Blalock anastomosis could not be found, and was probably not functioning.

A type I head hunter catheter (USCI No. 007815) was used to cannulate the Blalock anastomosis on the left (Fig. a). Once cannulated, a No. 3 French small diameter Teflon catheter (USCI No. 008649) was advanced down the head hunter catheter using a flexible guidewire. The pulmonary artery was entered without difficulty (Fig. b, no guidewire). A flush using contrast media was used for localisation purposes, and pulmonary artery pressure was measured at $32 / 18$ $\mathrm{mmHg}$, with a mean of $25 \mathrm{mmHg}$. Blood was not withdrawn through the catheter because of its small lumen size, and the catheter was withdrawn at the end of the procedure. The gradient measured in the Blalock anastomosis was $124 \mathrm{mmHg}$. The patient was referred for surgical repair.

\section{Discussion}

The technique of subselective coronary artery cannulation for coronary artery balloon dilatation, as pioneered by Gruntzig, ${ }^{3}$ or the administration of streptokinase ${ }^{5}$ has made available new equipment and technology that can be applied in situations other than originally intended.

The ability to use a technique of cannulation of a selected vessel with a preformed catheter, followed by the advance of a second catheter down that vessel, may well have an impact in other areas of cardiology.

Often, in a patient with cyanotic heart disease, pulmonary arterial pressures cannot be measured because of the abnormal anatomy. ${ }^{2}$ In the older cyanotic patient, especially those who have had a surgical procedure, further decisions about surgical intervention are often based on the ability to measure or reflect the pulmonary arterial pressures. 1 Many methods have attempted to deal with this dilemma, and all have some strengths and some weaknesses. ${ }^{7-12}$ In a patient with cyanotic heart disease and a functioning shunt, the use of subselective coronary angiographic techniques, developed for coronary balloon and/or streptokinase infusion, may well be helpful in obtaining pulmonary arterial pressures. The head hunter and No. 3 French Teflon catheter were used in this case instead of a Gruntzig guiding and balloon catheter because of their smaller size and lower cost. The forthcoming size reduction in coronary artery balloon dilatation guiding catheters may offer further versatility. ${ }^{13}$ It is unfortunate that the very small size of the internal lumen of the subselective catheter does not allow adequate blood sampling or contrast injection. In our case, a hand injection was adequate to see that the catheter was in the pulmonary artery and that both pulmonary arteries were present. With advances in 
technology, these deficiencies may be corrected.

It may prove prudent for those who do not perform either coronary. artery balloon dilatation or streptokinase infusion to acquaint themselves with the techniques and the equipment available.

\section{References}

1 Vogel JHK. Pulmonary hypertension. In Moss AJ, Adams FH, Emmanouilides CG, eds. Heart disease in infants, children, and adolescents. 2nd ed. Baltimore: Williams and Wilkins, 1977: 629.

2 Noonan JA, Nadas AS, Rudolph AM, Harris GBC. Transposition of the great arteries: a correlation of clinical, physiologic and autopsy data. $N$ Engl $\mathcal{F}$ Med $1970 ; 263$ : 592-6, 637-42, 684-92, 739-44.

3 Gruntzig AR, Senning A, Siegenthaler WE. Nonoperative dilatation of coronary-artery stenosis: percutaneous transluminal coronary angioplasty. $N \mathrm{Engl}$ F Med 1979; 301: 61-8.

4 Robertson WS, McHenry PL, King RD, Phillips JF, Morris SN, Dillon JC. Percutaneous transluminal coronary artery dilatation. $\mathcal{F}$ Indiana State Med Assoc 1982; 75: 98-104.

5 Kanmatsuse K, Lando U, Mercier JC, Fishbein MC, Swan HJC, Ganz W. Rapid lysis of coronary thrombi by local application of fibrinolysin (abstract). Circulation 1979; 60, suppl II: 11-216.
6 Ganz W, Buchbinder N, Marcus $\mathrm{H}$, et al. Intracoronary thrombolysis in evolving myocardial infarction. Am Heart J 1981; 101: 4-13.

7 Kjellberg SR, Mannheimer E, Rudhe M, Jonsson B. Diagnosis of congenital heart disease. Chicago: Year Book Publisher, 1955.

8 Weissel W, Salzmann F, Vetter H. Pulmonary capillary arterial pressure pulse in man. Br Heart f 1952; 14: 47-52.

9 Tybjaerg Hansen A, Fabricius J, Pedersen A, Sandøe E. Suprasternal puncture of the left atrium and the great vessels. Experience from 500 punctures. Am Heart $\mathcal{F}$ 1962; 63: 443-50.

10 Grollman JH Jr, Edson Price J Jr, Gray RK. Percutaneous transfemoral right heart catheterization. The pulmonary wedge catheter. Am f Cardiol 1972; 30: 646-7.

11 Nihill MR, Mullins CE, McNamara D. Visualization of the pulmonary arteries in pseudotruncus by pulmonary vein wedge angiography. Circulation 1978; 58: 140-7.

12 Nihill MR, McNamara DG. Magnification pulmonary wedge angiography in the evaluation of children with congenital heart disease and pulmonary hypertension. Circulation 1978; 58: 1094-106.

13 Gruntzig AR. Percutaneous transluminal angioplasty in coronary occlusion. Hosp Pract 1981; 129-36.

Requests for reprints to Dr James C Dillon, Indiana University School of Medicine, University Hospital, N-562, 926 West Michigan Street, Indianapolis, Indiana 46202, USA.

\section{Notices}

\section{Subacute bacterial endocarditis}

A survey is currently being carried out by the British Cardiac Society and the Medical Services Study Group of the Royal College of Physicians. Though improvement of dental prophylaxis is one objective, the survey is already yielding other valuable information. It is hoped that proformas will be received in respect of a high proportion of patients with subacute bacterial endocarditis in the British Isles seen during 1981 and 1982 and readers are asked to arrange for them to be submitted in respect of any cases that come to their notice. Proformas can be obtained from Sir Cyril Clarke, Medical Services Study Group, King's Fund Centre, 126 Albert Street, London NW1 7NF (tel. 01-267 6111, ext 263) to whom they should be returned.

\section{British Cardiac Society}

The Autumn Meeting 1982 will take place on 6 and 7 December. The closing date for receipt of abstracts was 11 August.

The Annual General Meeting for 1983 will take place in Bristol on 12 and 13 April, and the closing date for abstracts will be 4 January 1983 .

The Autumn Meeting will be held at Wembley on 21 and 22 November 1983, and the closing date for abstracts will be 28 July 1983 . 